\title{
FUNGOID DISEASES OF GALEGA ORIENTALIS
}

\author{
${ }^{1}$ L. V. Kyrylenko, ${ }^{2}$ V. P. Patyka \\ ${ }^{1}$ Vinnytsia National Agrarian University \\ ${ }^{2}$ D. K. Zabolotnyi Institute of Microbiology and Virusology, NASU
}

It was established that the major fungoid diseases of Galeca orientalis of Kavkazkyi branets variety under cultivation in woodland of Ukraine are rust, brown spot, ramularia, cercosporosis. Less commonly, plants are affected by downy mildew, ascochytosis, powdery mildew, gray rot.

Key words: Galeca orientalis, phytopathogens, monitoring, causative agents of fungoid diseases.

Galega orientalis is a highly prospective culture for fodder production and animal breeding in Ukraine, and unlikely from other legumes its is able to improve environmental state of agroecosystems of our country by enriching soil with biological nitrogen is adopted from the atmosphere by rhizobia in symbiosis with plants, accumulating $300 \mathrm{~kg} / \mathrm{ha}$ and more nitrogen in the topsoil during the vegetation period $[1 ; 5 ; 8 ; 16 ; 17]$. But the formation and functioning of legume-rhizobial symbiosis is significantly impacted by abiotic, biotic, and antropogenic environmental factors. Among biotic ones, special role is played by soil microorganisms, especially phytopathogenic fungi that are pathogens of Galega orientalis diseases. While accumulating in the soil, the latter causes increase its toxicity, which is manifested in inhibition of plant growth and reduction of crops productivity, leading to huge economical losses $[11 ; 12 ; 18]$.

In order to obtain high and quality yields of green mass of Galega orientalis it is required to perform timely control of fungal diseases that may affect this culture along with the other phytopathogenic microorganisms leading to the reduction of its crops, worsening of raw material quality and its poor storage.

Among the diseases of cultural plants, fungal ones are considered as the most common. First of all, due to the large number of causative agents, this comprises about 20 thousand, secondly - due to the relatively easy penetration into the feeding plant and ability to affect plants during all phases of their development [14]. Infestation of Galega orientalis with fungal diseases can be significant, reaching almost $30 \%$ [11]. At the same time, technological peculiarity of feeding grasses cultivation, to which Galega orientalis belongs, is their mowing that can be 2-3 times per vegetation. This explains prevalence of bacterial blight causative agent of which penetrates plant tissues through damaged surface.

The basis of mechanism of pathogenic action of phytopathogenic fungi includes violation in trophic chains, since following penetration into the feeding plants these phytopathogens become acceptors of plant assimilates, forming their deficit, and secondly - they can produce toxins and many enzymes that destroy carbohydrate polymers of cellular walls. The negative result of such interaction is distortion of plant metabolism. Parenchymal and vascular lesions, necrotization of certain tissues or organs due to mycoses, turns plant into the source of distribution of fungal infection. Died off residues of plants create infectious background that contributes to further distribution of pathogens. Although the mechanisms of pathogenic action of different types of fungi can differ significantly, all of them cause significant harm to agricultural manufacture, reducing 
the yield of economically valuable organs, its quality and shelf life. Fungal diseases are especially dangerous for Galega orientalis during the first year of plant cultivation [1113].

Plant diseases generated interest of the ancient Roman scholars [10; 19]. Domestic scientists S. P. Nadkernychnyi, V. P. Patyka, R. I. Hvozdiak, L. A. Pasichnyk, O. V. Nadkernychna, O. N. Kosmynina, T. V. Arystovska, O. A. Berestetskyi dedicated number of works to researches on the impact of pathogenic microorganisms on symbiosis of legume plants with rhizobia $[2 ; 3 ; 6 ; 7 ; 9]$. At the same time it should be noted that although fungal disease of Galega orientalis are the most studied among other legume pathogens, however, according to the available data, the number of species of fungi on Earth amounts several million of which only 69-120 thousand have been described. Species [4; 20-22]. In this regard, constant monitoring of not only distribution of well-studied fungal diseases of Galega orientalis in Ukraine is required, but also new, not typical for our country. The above is particularly relevant in connection with the introduction of new varieties of Galega orientalis of foreign selection. In addition, uncontrolled importation of Galega orientalis seeds can become a source of previously unknown fungal diseases for Ukraine.

The aim of our work was perform monitoring studies and identification of causative agents of fungal diseases of Galega orientalis agrophytocenosis.

\section{Materials and methods.}

Experimental part of the work was performed during 2011-2016 in vegetation and laboratory experiments of the Phytopathogenic Bacteria Department of D. K. Zabolotnyi Institute of Microbiology and Virology and the Department of Symbiotic Nitrogen Fixation of the Institute of Plant Physiology and Genetics of the NAS of Ukraine, as well as under conditions of experimental field of Vinnitsa National Agrarian University and Vinnytsia State Agricultural Experiment Station of the Institute of Feed and Agriculture of Podillia of the NAAS and at the fields of agricultural enterprises of the District of Orativ, Region of Vinnytsia. Variety of Galega orientlais Kavkazkyi branets.

The soil at the experimental plot of Vinnytsia National Agrarian University grey forest middle loamy. According to the data of agrochemical examination, content of humus in the topsoil is low $-3 \%$. Content of easily hydrolysed nitrogen (By Cornfield) is low $-7.0-8.0 \mathrm{mg} / \mathrm{kg}$, mobile phosphorus (by Chyrykov) is high - 16.0$19.4 \mathrm{mg} / \mathrm{kg}$ of soil, exchangeable potassium (by Chyrykov ) is increased $-9.5 \mathrm{mg} / \mathrm{kg}$ of soil, $\mathrm{pH}_{\text {sal. }}-5.0-5.4$. Hydrolytic acidity is of $4.32 \mathrm{mEq} . / 100 \mathrm{~g}$ of soil.

Investigation of culturalmorphological and physiologicalbiochemical signs of Rhizobium galegae was conducted according to generally accepted methods of soil microbiology [6; $10]$.

Microbiological analysis was performed using the dilution method of soil suspensions with digest selective media [2; $6 ; 10]$.

Thus, the most widespread phytopathogenic fungal diseases of Galega orientalis of variety Kavkazkyi branets are rust, brown spot, ramularia, cercosporosis, rarely - downy mildew, black stem, powdery mildew, gray mould. The most common factors of spreading of pathogenic fungal mycoses are weather conditions: humidity, air temperature. 